\title{
Immunomodulatory Effects of Green Tea Polyphenols ${ }^{\dagger}$
}

\author{
Shuzhen Wang ${ }^{1}$, Zhiliang $\mathrm{Li}^{1}$, Yuting Ma ${ }^{1}$, Yan Liu ${ }^{1}$, Chi-Chen $\operatorname{Lin}^{2}{ }^{2}$, Shiming $\mathrm{Li}^{1,3, *}$, Jianfeng Zhan ${ }^{1}$ and \\ Chi-Tang Ho ${ }^{3, *}$ (D)
}

1 Hubei Collaborative Innovation Center for the Characteristic Resources Exploitation of Dabie Mountains, Hubei Zhongke Research Institute of Industrial Technology, College of Life Science, Huanggang Normal University, Huanggang 438000, China; wangshuzhen710@whu.edu.cn (S.W.); swlzl@hgnu.edu.cn (Z.L.); 2019230240127@smail.hgnu.edu.cn (Y.M.); 2019230240405@smail.hgnu.edu.cn (Y.L.); swzjf@hgnu.edu.cn (J.Z.)

2 Institute of Biomedical Science, The iEGG and Animal Biotechnology Center, National Chung-Hsing University, Taichung 402, Taiwan; lincc@dragon.nchu.edu.tw

3 Department of Food Science, Rutgers University, New Brunswick, NJ 08901, USA

* Correspondence: shiming@rutgers.edu (S.L.); ctho@sebs.rutgers.edu (C.-T.H.)

+ This article is dedicated to the lifetime achievements of Professor Fereidoon Shahidi in "Advances in Food Chemistry, Nutraceuticals, Functional Foods, and Dietary Bioactives".

Citation: Wang, S.; Li, Z.; Ma, Y.; Liu, Y.; Lin, C.-C.; Li, S.; Zhan, J.; Ho, C.-T. Immunomodulatory Effects of Green Tea Polyphenols. Molecules 2021, 26, 3755. https://doi.org/10.3390/ molecules26123755

\section{Academic Editors:}

Ryszard Amarowicz and Adriano Costa de Camargo

Received: 26 May 2021

Accepted: 18 June 2021

Published: 20 June 2021

Publisher's Note: MDPI stays neutral with regard to jurisdictional claims in published maps and institutional affiliations.

Copyright: (C) 2021 by the authors. Licensee MDPI, Basel, Switzerland. This article is an open access article distributed under the terms and conditions of the Creative Commons Attribution (CC BY) license (https:// creativecommons.org/licenses/by/ $4.0 /)$.

\begin{abstract}
Green tea and its bioactive components, especially polyphenols, possess many healthpromoting and disease-preventing benefits, especially anti-inflammatory, antioxidant, anticancer, and metabolic modulation effects with multi-target modes of action. However, the effect of tea polyphenols on immune function has not been well studied. Moreover, the underlying cellular and molecular mechanisms mediating immunoregulation are not well understood. This review summarizes the recent studies on the immune-potentiating effects and corresponding mechanisms of tea polyphenols, especially the main components of (-)-epigallocatechin-3-gallate (EGCG) and (-)-epicatechin-3-gallate (ECG). In addition, the benefits towards immune-related diseases, such as autoimmune diseases, cutaneous-related immune diseases, and obesity-related immune diseases, have been discussed.
\end{abstract}

Keywords: green tea polyphenols; immunomodulatory; autoimmune diseases; anti-inflammatory action; epigallocatechin-3-gallate (EGCG)

\section{Introduction}

The human immune system has developed defensive components possessing functions specialized for mucosal areas, such as mucus and its constituents, secretory immunoglobulins, and unique subsets of leukocytes localizing to or maturating in mucosal regions [1]. Mucosal surfaces are the interfaces between the external and internal environments, through which gases, nutrients, waste products, and other materials can move [2]. At the same time, mucosal surfaces also provide ideal sites for the entry of pathogens. Immunomodulation encompasses immunostimulation or immunoinhibition of certain cellular and/or humoral immune responses. These defensive components prevent attachment and entry of pathogens to host tissues and mobilize other immune components after the entry of microbes, which ultimately resist against particular pathogens or foreign substances [1]. Particularly, the sophisticated immune response relies on the reactions of a number of germline-encoded pattern-recognition receptors (PRRs) with conserved pathogenic structures of pathogen-associated molecular patterns (PAMPs) [3,4].

The most extensively studied PRRs is the Toll-like receptor (TLR) family, which can be further divided into several subfamilies based on recognized ligands: TLRs 1, 2, and 6 identifying lipopeptides and glycolipids; TLRs 7, 8, and 9 recognizing nucleic acids (ssRNA and unmethylated $\mathrm{CpG}$ ); TLR3 distinguishing dsRNA associated with viral infection; TLR4 recognizing fibronectin, lipopolysaccharides (LPS), and heat shock proteins; TLR5 recognizing bacterial flagellin; TLRs 11 and 12 recognizing profilin and actin-binding protein 
(Table 1) [5]. TLRs are expressed by a variety of immune cells, including T cells, B cells, dendritic cells (DCs), and natural killer (NK) cells. NK cells express high levels of TLRs 1, 3 and $6[6,7]$. DCs express TLRs 2, 4, 7, and 9 [8]. Human peripheral blood T cells express TLRs $1-5,7$, and 9 [9]. B cells mainly express TLRs 3, 4, and 9 [10]. In particular, TLR2 binds to a wider range of ligands in recognizing bacterial, viral, fungal, and endogenous substances. Moreover, dimerization of TLR2 with TLR 6 or TLR1 is vital for identifying bacterial lipoproteins and lipopeptides [11]. TLR 2 serves as crucial targets for immunotherapy, especially in malignant diseases [12]. Once activated TLR 2, there is an increase in the nuclear transcription factor- $\mathrm{kB}(\mathrm{NF}-\mathrm{\kappa B})$, which induces expression of cytokines to enhance immunity. In humans, TLR 4 specifically recognizes bacteria LPS, endogenous molecules produced during tissue damage, and other pathogen components [13].

Table 1. TLR subfamilies and corresponding ligands.

\begin{tabular}{cc}
\hline TLR Subfamilies & Recognized Ligands \\
\hline TLR1, TLR2, TLR6 & lipopeptides and glycolipids \\
TLR7, TLR8, TLR9 & nucleic acids (ssRNA and unmethylated CpG) \\
TLR3 & dsRNA associated with viral infection \\
TLR4 & fibronectin, lipopolysaccharides (LPS), and heat shock proteins \\
TLR5 & bacterial flagellin \\
TLR11, TLR12 & profilin and actin-binding protein \\
\hline
\end{tabular}

The activation of TLRs with corresponding ligands could affect myeloid and lymphoid progenitors, and trigger signaling cascades leading to production of pro-inflammatory cytokines and chemokines. After pathogen recognition, the TLR signal transduction is initiated through the toll/interleukin 1 receptor (TIR) domain [5]. Most TLRs use a TIRcontaining adaptor MyD88 to trigger a certain signaling pathway, in which activated NF- $\mathrm{kB}$ induce expression of critical genes for inflammatory cytokines [14]. MyD88, a downstream adaptor protein of mammalian TLR and Interleukin (IL)-1 receptor (IL-1R) families, can link TLRs to IL-1R associated kinases (IRAKs), leading to the activation of NF- $\mathrm{KB}$, activator protein 1, and MAPKs [14]. Therefore, MyD88 is a critical player in inflammatory signaling pathways. The dysregulated activity of TLR is often associated with high risk of chronic inflammatory and immune diseases, such as aging, immunosenescence, and even autoimmune diseases including diabetes, inflammatory bowel disease, rheumatoid arthritis, hepatitis, and systemic lupus erythematosus [15-17].

Natural products and their derivatives exert immunomodulatory effects on chronic diseases through stimulating various branches and components of the immune system, and are promising as anti-oxidative, antimicrobial, regulation of metabolism, anti-inflammatory, anticancer, as well as cardiovascular protective and neurological protective agents $[5,18]$. In particular, natural products, such as herbal medicines, probiotics, vitamins, polyphenols, and fatty acids, have been demonstrated to possess immunomodulatory actions [19]. Today, about $70 \%$ of drugs on the market originate directly or indirectly from natural sources [20]. Many phytochemicals exert their action by targeting TLRs and their signaling molecules downstream. In particular, green tea, obtained from the leaves of Camellia sinensis, possesses important medicinal value. The green tea polyphenols (GTPs), especially (-)-epigallocatechin-3-gallate (EGCG) and (-)-epicatechingallate (ECG) (Figure 1), can greatly enhance immune response and lower the risk of inflammation and immune-related diseases [21,22]. 
(A)

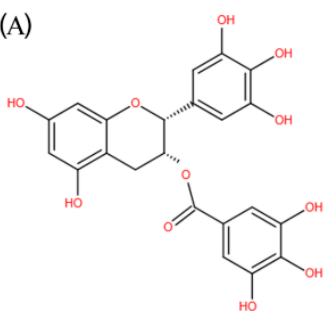

(B)

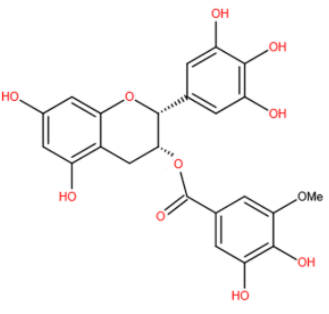

(C)

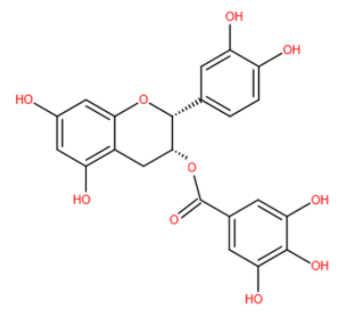

Figure 1. Chemical structure of EGCG (A), EGCG3"Me (B), and ECG (C).

Health-promoting multifunctionality has been well illustrated for tea polyphenols, especially anti-inflammatory, antioxidant, anticancer effects, and metabolic modulation with multi-target action [23]. As natural immune modulators, tea polyphenols could control and defeat disorders affecting immune system through up- or down-regulating immune responses without undesired adverse effects [23]. In the present review, the advancements in recent 30 years for utilizing green tea polyphenols for immunomodulation, as well as their molecular and cellular mechanisms to modulate inflammation, have been summarized. Moreover, important molecular targets of green tea polyphenols have also been clarified, hoping to bring broad application of green tea as functional foods.

\section{Immune Potentiating Effects of Tea Polyphenols}

GTPs and their derivatives act through stimulating multiple TLR signaling pathways in human and could effectively inhibit proliferation of murine lymphocytes (Table 2) [24]. EGCG, comprising approximate $55-70 \%$ of total tea polyphenols, exerted immunomodulatory effects on tumor immunity in different pre-clinical models, and was exploited for treatment of chemo-insensitive but immunologically responsive tumors [25]. Moreover, EGCG inhibited IKK $\beta$, a downstream signaling molecular of MyD88-dependent pathway [26]. Furthermore, EGCG also inhibited NF- $\mathrm{kB}$ activation induced by TLR4 and TLR2 agonists [26]. EGCG could prevent the production of interferon gamma (IFN $\gamma$ ) by SEB (Staphylococcus aureus enterotoxin B)-stimulated peripheral blood mononuclear cells [27]. Moreover, EGCG could reduce the depletion of antigen-presenting cells (APCs), and prevent ultraviolet-induced immunosuppression $[28,29]$. In vitro, EGCG could suppress the maturation of mouse bone marrow-derived and human monocytes-derived DCs, which were the main APCs [29-31]. In invertebrate Kuruma shrimp Marsupeneaus japonicus challenged with white spot syndrome virus (WSSV) and the Gram-negative bacterium Vibrio alginolyticus, EGCG pretreatment significantly delayed and reduced mortality through regulating expression of innate immune-related genes, such as IMD, proPO, QM, myosin, Rho, Rab7, p53, TNF- $\alpha, M A P K$, and NOS [32]. In the shrimp innate immune system, EGCG could serve as an enhancer of immune parameters (total hemocyte count, phenoloxidase, and superoxide dismutase activities) and an inhibitor of apoptosis, finally delaying or even reducing mortality upon pathogen challenge [32].

The Th1 and Th2 are critical members in cell- and humoral-mediated immunity, respectively. In the body, Th1/Th2 keeps a dynamic balance, which is vital for maintaining sound immune function. GTPs partially reduced IFN $\gamma$-induced phosphorylation and function of STAT1, prevented upregulation of inducible nitric oxide synthetase (iNOS) 2 and NF- $\mathrm{kB}$, and inhibited transcription and secretion of TNF- $\alpha$ and IFN $\gamma$, all inferring that GTPs may preferentially inhibit Th1-like T cell immunity [33-35]. GTPs might also inhibit these intracellular signals, which are involved in T cell activation and differentiation into Th1-like effector cells. GTPs supplementation could elevate the anti-inflammatory cytokine IL-4, which is necessary for the proliferation and activation of Th2 cell [36]. Dietary GTPs could decrease the ratio of IFN $\gamma / \mathrm{IL}-4$, an index of Th1/Th2 [36].

\subsection{Effects on Cellular Immunity}

$\mathrm{T}$ cells could release various cytokines, stimulate $\mathrm{B}$ cell activation and proliferation, and improve immune response [37]. The $\mathrm{CD} 4+\mathrm{T}$ cells participate in recognizing antigens 
presented by MHC type II (exogenousAg), and CD8+ T cells participate in the recognition of antigens presented by MHC type I (endogenous Ag). The ratio of CD4+/CD8+ $(<1)$ refers to a sign of immunodeficiency [37]. Dietary GTPs enhance defense ability of the host against exogenous infection through promoting immune cell proliferation, activating $\mathrm{T}$ lymphocytes, elevating the percentage of $\mathrm{CD} 4+\mathrm{T}$ cell, elevating the ratio of $\mathrm{CD} 4+/ \mathrm{CD} 8+$, improving T lymphocyte transformation (LTT), and recovering cells from immune damage caused by oxidative stress in piglets [36]. In mixed lymphocyte reactions, GTPs could effectively inhibit IFN $\gamma$ secretion by cultured monoclonal T cells and alloreactive T cells, and the inhibitory effects in vitro were routinely notable at 3-20 $\mu \mathrm{g} / \mathrm{mL}$ [38]. Oral GTPs could significantly prolong the minor antigen-disparate skin graft survival, significantly induce apoptosis of T cells and APCs, as well as greatly decrease the frequency of donorreactive IFN $\gamma$-producing $\mathrm{T}$ cells in recipient secondary lymphoid organs [38]. However, oral GTPs could not alter DCs trafficking to lymph nodes or affect metalloproteinase activity in the skin graft [38]. In addition, GTPs could influence both the expression of T-cell receptor complex and antigen-specific T-cell responses [39].

EGCG $(2.5-15 \mathrm{mM})$ could inhibit $\mathrm{T}$ cell division and cycle progression in a dosedependent manner, and the inhibitory effect was more pronounced in CD4+ $\mathrm{T}$ cells than $\mathrm{CD} 8+\mathrm{T}$ cells [38]. Compared with CD8+ $\mathrm{T}$ cells, $\mathrm{CD} 4+\mathrm{T}$ cells were more responsive to EGCG [38]. At a physiologically relevant concentrations (2.5-10 mmol/L), EGCG inhibited splenocyte proliferation stimulated by $\mathrm{T}$ cell mitogen concanavalin A (Con A) in a dosedependent manner [40]. Moreover, T cell division and cell cycle progression could also be inhibited by EGCG [40]. EGCG could also suppress the LPS-induced phenotypic and functional maturation of murine DCs through inhibiting the mitogen-activated protein kinases (MAPK) and NF-KB [30]. In mice, EGCG (0.3\%) directly inhibited T cell proliferative response to polyclonal and antigen-specific stimulation [41]. In 1-methyl-4-phenyl-1,2,3,6tetrahydropyridine (MPTP)-induced Parkinson's disease (PD) mouse model, EGCG could increase the ratio of $\mathrm{CD} 3+\mathrm{CD} 4+$ to $\mathrm{CD} 3+\mathrm{CD} 8+\mathrm{T}$ lymphocytes and modulate peripheral immune response [42]. In human primary T cells, EGCG $(10 \mu \mathrm{M}$ or $20 \mu \mathrm{M})$ tended to inactivate AP-1 DNA-binding activity, and decreased INF- $\gamma$ levels by $31.3 \%$ and $34.7 \%$, IL-2 levels by $26.0 \%$ and $38.8 \%$, IL-4 levels by $41.5 \%$ and $55.9 \%$, as well as TNF- $\alpha$ levels by $23.0 \%$ and $37.6 \%$, respectively [43]. Moreover, the level of p-JNK and p-ERK was also decreased by EGCG, but showing no effects to levels of p-p38 MAPK and total protein amounts [43].

Neutrophils are important in host defense and inflammation, though the latter might trigger and sustain several acute or chronic diseases. EGCG could inhibit metallo-elastase and serine-elastase secreted by macrophages and neutrophils, respectively [44,45]. EGCG could also reduce neutrophil transmigration through monolayers of endothelial cells [46]. In a transgenic zebrafish model, EGCG treatment reduced neutrophil response (accumulation, travel speed, and distance), downregulated the expression of IL-1 $\beta$, TNF- $\alpha$, and related signaling pathways [47]. Moreover, EGCG could inhibit apoptosis of activated neutrophils and chemokine-induced neutrophil chemotaxis in vitro, strongly inhibit neutrophil elastase, repress ROS activity, block neutrophil-mediated angiogenesis in vivo in an inflammatory angiogenesis model, enhance resolution in a pulmonary inflammation model, and significantly reduce consequent fibrosis [48]. GTPs inhibited TNF- $\alpha$ induction in macrophages through attenuating NF-kB activation [49]. In peritoneal macrophages, EGCG inhibited LPS-stimulated nitric oxide production and expression of iNOS through decreasing NF-KB activities [50]. In human peripheral blood mononuclear cells, EGCG could induce the production of neopterin, a marker of activated cellular immunity [51]. 
Table 2. The immune-potentiating effects of tea polyphenols.

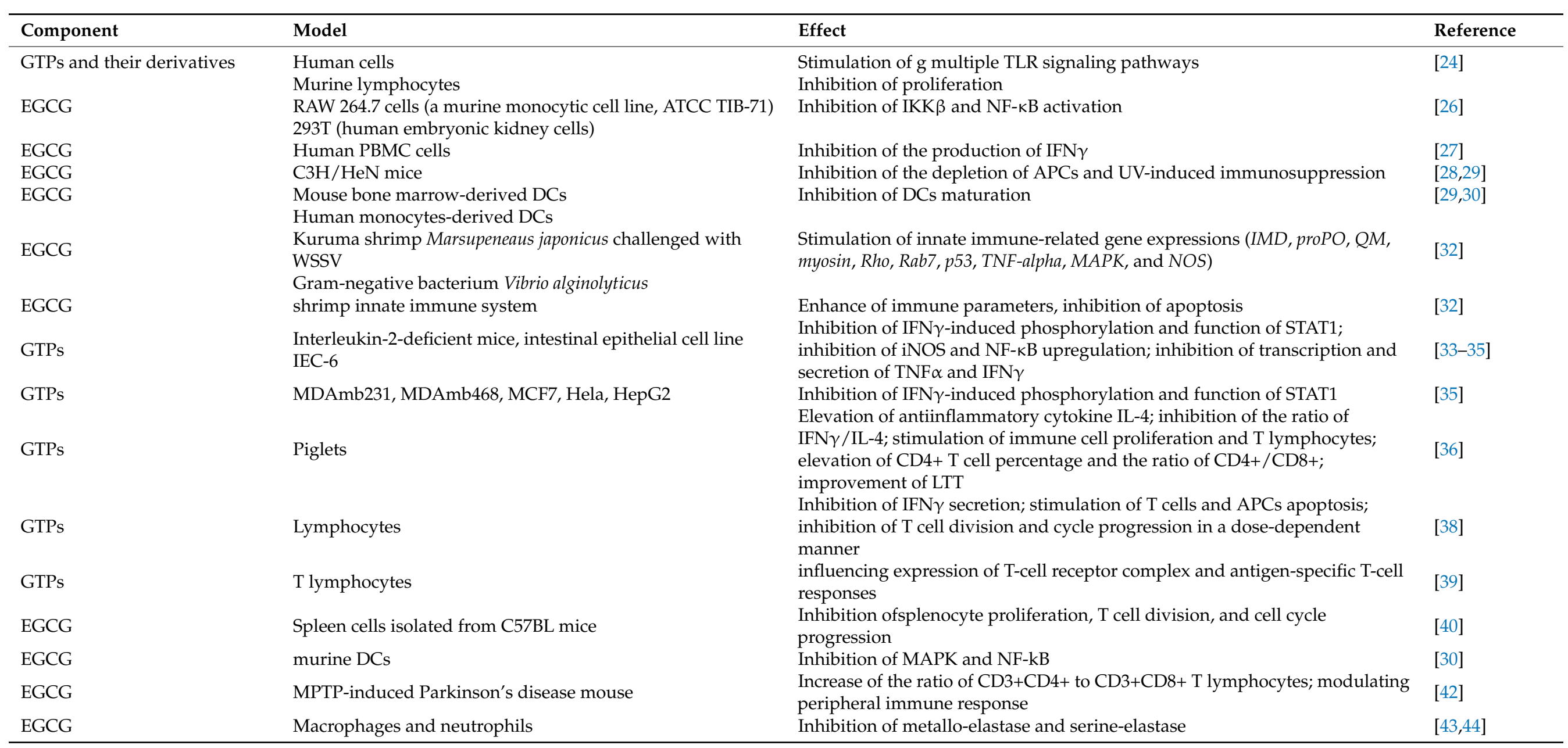


Table 2. Cont.

\begin{tabular}{|c|c|c|c|}
\hline Component & Model & Effect & Reference \\
\hline EGCG & Human umbilical vein endothelial cells & Inhibition of neutrophil transmigration & [45] \\
\hline EGCG & Transgenic zebra fish & $\begin{array}{l}\text { Inhibition of neutrophil response (accumulation, travel speed, and distance) } \\
\text { expression of IL- } 1 \beta \text { and TNF } \alpha \text {, as well as related signaling pathways }\end{array}$ & [46] \\
\hline EGCG & $\begin{array}{l}\text { Inflammatory angiogenesis model, pulmonary inflammation } \\
\text { model }\end{array}$ & $\begin{array}{l}\text { Apoptosis inhibition of activated neutrophils and chemokine-induced } \\
\text { neutrophil chemotaxis; inhibition of neutrophil elastase, ROS activity, } \\
\text { neutrophil-mediated angiogenesis, and fibrosis }\end{array}$ & [47] \\
\hline GTPs & Macrophages & Inhibition of TNF- $\alpha$ induction and NF-kB activation & [48] \\
\hline EGCG & peritoneal macrophages & $\begin{array}{l}\text { Inhibition of LPS-stimulated NO production, iNOS expression, and NF-kB } \\
\text { activities }\end{array}$ & [49] \\
\hline EGCG & Human peripheral blood mononuclear cells & Inducement of neopterin production & [50] \\
\hline Tea polyphenols & $\mathrm{BALB} / \mathrm{c}$ mice & $\begin{array}{l}\text { increase of antibody-secreted cells in spleen and IgM-mediated IgG-mediated } \\
\text { immune response }\end{array}$ & [51] \\
\hline GTPs & Mice & $\begin{array}{l}\text { Decrease of total IgG and type II collagen-specific IgG levels in serum and } \\
\text { arthritic joints, as well as the neutral endopeptidase activity }\end{array}$ & [52] \\
\hline EGCG & Mouse & $\begin{array}{l}\text { Enhancement of PFC response to sheep red blood cells, strong mitogenic } \\
\text { activity towards splenic B-cells }\end{array}$ & [53] \\
\hline GTPs & Wuchang bream juveniles & Elevation of content and mRNA levels of splenic IL- $1 \beta$, TNF $\alpha$ and IgM & [54] \\
\hline
\end{tabular}




\subsection{Effects on Humoral Immunity}

GTPs and their derived substances could stimulate B-cell proliferation and antibody production effectively (Table 2). In BALB/c mice, tea polyphenols exerted stimulatory effects on humoral immune response through increasing number of antibody-secreted cells in spleen, and significantly increased the immunoglobulin M (IgM)-mediated and IgG-mediated immune response to non-particulate antigen (BSA) and particulate antigen (SRBCs) in a dose-dependent manner [52]. In particular, splenocytes reached the highest $(344 \pm 10 / 106)$ on day 14 postimmunization $(p<0.001)$ [52]. In case of polyphenols, the mice showed a sharp increase in IgM and IgG antibodies on days 14 and 21, respectively [52]. In addition, GTPs significantly reduced total IgG and type II collagen-specific IgG levels in serum and arthritic joints, as well as the neutral endopeptidase activity [53]. In vitro, EGCG could strongly enhance the direct plaque-forming cell (PFC) response to sheep red blood cells (SRBC) and show strong mitogenic activity towards mouse splenic B-cells [54]. In particular, the galloyl group on EGCG was responsible for enhancement [54]. ECG, EGCG, and theaflavin digallate (TFDG) displayed significant enhancement of the spontaneous proliferation of B-cells, though with quite different potencies [54]. In healthy Wuchang bream juveniles, dietary GTPs could elevate the content and mRNA levels of splenic IL-1 $\beta$, TNF- $\alpha$ and IgM [55].

\section{Immunomodulation through Anti-Inflammatory Mechanism}

Inflammatory reactions are protective biological processes to eliminate harmful stimuli, which are performed by endogenous mediators, such as eicosanoids, oxidants, cytokines, chemokines, as well as lytic enzymes secreted by macrophages, neutrophils, and injured tissue itself [56,57]. Prostaglandins (PGs) and leukotrienes (LTs), critical factors involved in inflammatory responses, are produced in pathways catalyzed by cyclooxygenases (COX) and lipoxygenases (LOX) [58]. As a protective biological process, inflammation sometimes exerts detrimental outcomes in affected tissues, especially when reactive oxygen species (ROS) are produced. The highly reactive free radical nitric oxide (NO) can trigger toxic oxidative reactions, which will result in inflammation and tissue damage. Active PPAR $\gamma$ exerts anti-inflammatory roles through suppressing the expression of a wide range of pro-inflammatory genes (IL-1 $\beta, I L-6, T N F-\alpha, i N O S$, and MMP-9) in various cell types [59]. PPAR $\gamma$ activation could reduce inflammation through suppressing NF- $\kappa B$ activity, decreasing IKB $\alpha$ phosphorylation, covalently modifying NF- $\kappa B$ subunits for abrogated NF- $\mathrm{kB}-\mathrm{DNA}$ interaction, and inducing NF- $\mathrm{kB}$ nuclear export [59].

The beneficial effects of GTPs and EGCG have been observed in animal models of rheumatoid arthritis (RA) [60], chronic inflammatory bowel diseases [61], lupus nephritis [62], and multiple sclerosis (MS) [63]. GTPs modulate neutrophil-mediated- and lymphocyte-mediated inflammation in IL-2-deficient mice [33,48]. In male DBA/1 mice (H-2q), GTPs significantly reduced the incidence of arthritis (33\% to $50 \%$ ), and reduced inflammatory mediator expression in arthritic joints, including COX2, IFN- $\gamma$, and tumor necrosis factor [53]. Diets supplemented with GTPs significantly attenuated inflammation through reducing the increment of IL-1, which was mainly produced by mononuclear macrophage [36]. Moreover, GTPs-supplementation also reduced pro-inflammatory cytokine IFN secreted by Th1 cell through inhibiting the activities of IkB kinase (IKK) and NF-kB [36]. In NOD mouse model for Hashimoto's thyroiditis, GTPs administration led to an enhanced production of IL-10 by concanavalin A-stimulated splenocytes without interfering with thyroiditis development and serum thyroxine levels [64].

EGCG could inhibit infiltration of inflammatory leukocytes [28]. The expression of proinflammation IL-8 could also be inhibited by EGCG [65]. In MPTP-induced PD mouse model, EGCG treatment could effectively reduce the expression of inflammatory factors TNF- $\alpha$ and IL-6 in serum [42]. In dental pulp cells pre-treated with LPS or PG, ECG could effectively inhibit the production of IL-6 and IL-8 [66]. In HDPC cells, ECG mitigated pulpal inflammation mostly through reducing LPS-/PG-mediated VEGF production, and inhibiting COX-2 expression in a dose-dependent manner [67]. In the human hepatoma 
cell line HepG2, ECG significantly reversed IL-6, reduced synthesis of negative acute-phase protein transthyretin and retinol binding protein, and finally enhanced host defense mechanisms towards inflammation [68]. ECG showed anti-inflammatory effects in HGFs mainly via preventing IL-17A-mediated CC chemokine ligand-20 (CCL20) production, inhibiting activities of p38 MAPK and ERK, as well as attenuating IL-17 receptor expression [69]. In LPS- induced macrophages and endotoxemia, ECG showed anti-inflammatory effects through inducing Nrf2/ARE-driven GSH and HO-1 levels, interfering with NF- $\mathrm{kB}$ and Nfr2/ARE transcriptional activities, and even suppressing MAPKs and PI3K/Akt signaling pathways [70]. ECG could intracellularly interact with Kelch repeat domains of Keap1, bind to extra cellular LPS, promote nuclear accumulation of Nrf2 proteins, blockade ERK1/2 and Nrf2/ARE signaling pathways, and ultimately attenuate pathological syndromes of LPS-induced sepsis and systemic inflammation (Figure 2) [21,70].

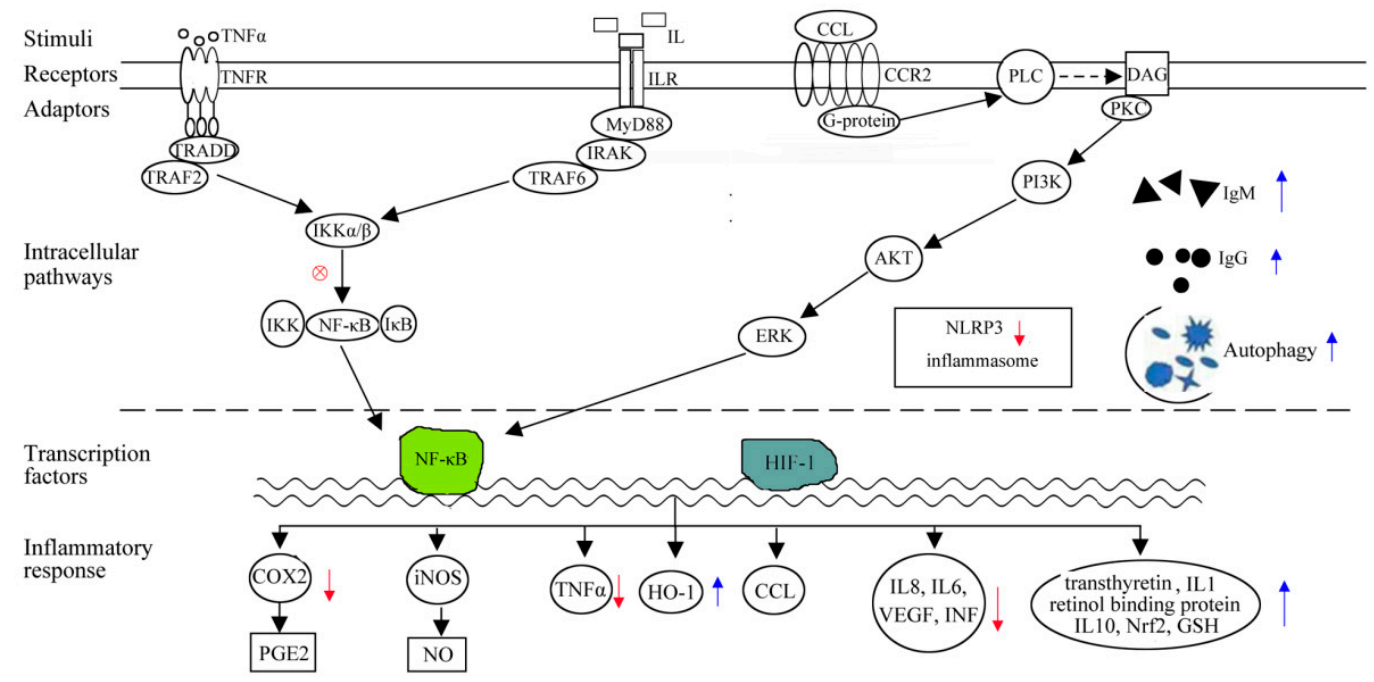

Figure 2. Schematic illustrating the immunomodulation mechanisms of GTPs and EGCG through anti-inflammatory mechanism.

In an acute gout mouse model, oral administration of EGCG effectively alleviated gout inflammatory symptoms in foot tissue injected with monosodium urate (MSU) crystals, inhibited the de novo synthesis of mitochondrial DNA, and induced the production of ROS in primary macrophages [71]. Moreover, the in vivo suppressive effects of EGCG in mouse foot tissue were closely correlated with the suppression of NLRP3 inflammasome [71]. In mouse with gout disease, EGCG could suppress the activation of NLRP3 inflammasome in macrophages through blocking mitochondrial DNA synthesis, which contributed a lot to the prevention of gouty inflammation [71]. The inhibitory effects of EGCG on the NLRP3 inflammasome make EGCG a promising therapeutic option for NLRP3-dependent gout diseases, a chronic inflammatory disease evoked by the deposition of MSU crystals in joint tissues [71]. Oral or intravenous infusion of EGCG could reduce mRNA and protein expression of renal NLRP3 in lupus nephritis mouse model and contrast-induced nephropathy rat model, possibly leading to the reduction of NLRP3 inflammasome activation [61,72]. In mice with PFDA-induced liver damage and inflammation, GTPs or EGCG extended the survival time, inhibited weight loss, improved hepatic oxidative stress, cell apoptosis, steatosis, edema, necrosis, and degeneration, reduced hepatic inflammation and NLRP3 inflammasome activation [73].

\section{Immunomodulation through Antioxidation Mechanism}

Uncontrolled oxidative stress serves as the molecular basis of several immune-impaired pathologies [74]. Biotic and abiotic stressors, such as disease and chemical toxins, can result in over accumulation of ROS beyond the scavenging capability of the body, which is known 
as oxidative stress [74,75]. Particularly, the imbalance between generation of ROS and antioxidant defense capacity of body is closely associated with many dysfunctions, such as impaired immunity [75]. If immune cells are exposed to deleterious infection, they usually release ROS to eliminate exogenous invaders, and the ROS level is of physiologic relevance and very important for cell protection [37]. At the same time, the cumulative ROS may render host subjecting to oxidative stress and impair host $\mathrm{T}$ cell processes [76]. Oxidative stress is also blamed due to mediating diseases characteristic of immunodeficiency, including kidney failure, hypertension, ischemic-reperfusion injury, and alcoholic liver disease [77-79]. ROS, such as free radicals, oxygen ions, and peroxides, are implicated in cell damage and vital for host defense, which are frequently associated with inflammation [76]

GTPs have a special structure of polycyclic aromatic hydrocarbons, which can reduce oxidative free radicals and prevent critical cellular components from being oxidized [80]. Based on research in nutritional immunology, dietary GTPs are effective in meliorating immune related diseases through attenuating oxidative stress [36]. In piglets subjected to oxidative stress, dietary GTPs could promote proliferation and activation of $\mathrm{T}$ lymphocytes, elevate the ratio of CD4+/CD8+, attenuate the level of pro-inflammatory IL-1, decrease the concentration of serum IFN- $\gamma$, enhance serum concentrations of anti-inflammatory cytokine IL-4, lead the immune shift from Th1 to Th2, and alleviate growth depression, which showed significantly immunomodulatory potentials [36]. In juvenile black carp Mylopharyngodon piceus, GTPs $(25-500 \mathrm{mg} / \mathrm{kg})$ remarkably increased the content of serum superoxide dismutase (SOD) and glutamic oxalacetic transaminase (GOT), but decreased the contents of glutathione (GSH), glutathione peroxidase (GSH-Pox), malondialdehyde (MDA), cortisol, triglyceride (TG) and low-density lipoprotein cholesterol (LDL-C) at significant level $(\mathrm{p}<0.05)$ [80]. GTPs could effectively improve the growth performance and oxidative capacity on juvenile black carp with the optimal dosage of $50 \mathrm{mg} / \mathrm{kg}$ [80]. In healthy Wuchang bream juveniles, dietary GTPs have elevated the total antioxidant capacity through increasing contents of catalase and glutathione peroxidase in serum before and after ammonia exposure and reduce serum cortisol level [55]. In sleep disordered breathing rodents, GTPs could mitigate intermittent hypoxia-induced oxidative stress through reducing lipid peroxidation and decreasing the level of PGE2 [81].

ECG could catalyze oxidative DNA degradation in lymphocyte cell nuclei through mobilization of nuclear copper and induction of ROS production [82]. In dental pulp cells pre-treated with LPS or PG, ECG could effectively inhibit IL-6 and IL-8 production [66]. In HDPC cells, ECG could mitigate pulpal inflammation via reducing LPS/PG-mediated VEGF production, as well as inhibit COX-2 expression [66].

\section{Benefits on Human Microbiota and Corresponding Immunological Implications}

Green tea polyphenols could strongly reduce the body fat content, as well as hepatic triacylglycerol and cholesterol accumulation. In particular, the reduction was negatively correlated to the amount of Akkermansia and the total amount of intestinal bacteria [83]. A dysfunctional gut microbiota might participate in the pathogenesis of type 2 diabetes [83]. In C57BL/6J mice, green tea powder in combination with Lactobacillus plantarum could promote growth of Lactobacillus in the intestine, improve the diversity of intestinal bacteria, and attenuate high fat diet-induced inflammation [83]. In volunteers who did not usually consume green tea, green tea consumption acted as a prebiotic and improved the colon environment by increasing the proportion of the Bifidobacterium species [84]. Fermented green tea extract restored the changes in gut microbiota composition, including the ratios of Firmicutes/Bacteroidetes and Bacteroides/Prevotella, which is closely related with the development of obesity and insulin resistance [85]. In has been speculated that the fermented green tea extract improved obesity and other associated symptoms through modulating composition of gut microbiota, as mRNA expression levels of lipogenic and inflammatory genes were significantly downregulated in the white adipose tissue of mice [85]. Based on the high-throughput MiSeq sequencing and multivariate statistical analysis, green tea infusion consumption substantially increased diversity and altered the structure of gut 
microbiota in high-fat-diet induced obese C57BL/6J mice, which further exerted antiobesity and anti-inflammatory activities [86]. Diversity of the total bacterial community reached the maximum after GTP treatment for almost 3 weeks, and then decreased when the mice were fed without GTP [87]. In particular, the relative abundance of Bacteroidetes increased from $0.56 \pm 0.06$ (1st week) to $0.60 \pm 0.05$ (3rd week), but Firmicutes decreased from $0.42 \pm 0.06$ (1st week) to $0.37 \pm 0.02$ (3rd week) [87]. Interestingly, Bacteroidetes and Proteobacteria still increased, but Firmicutes decreased even when the mice were fed without GTP (4th week) [87]. GTP could benefit the stability of certain gut microbiota in an environment-triggered microbial imbalance situation, providing prebiotic-like activity contributing to anti-obesity and anti-inflammatory effects. GTPs could boost mammal energy conversion by modulating gut-microbial community structure, gene orthologs, and metabolic pathways [88]. Following the increase of beneficial microbials in families Clostridia, Ruminococcaceae, Lachnospiraceae, and Bacteroidaceae, metabolic modulation could also been achieved through enriching many gene orthologs [88]. In rats, GTPs could enhance energy conversion through boosting mitochondrial TCA cycle and urea cycle of gut-microbiota [88]. Based on HILIC-HESI-tandem LC-MS, remarkable changes of 39 metabolites in the mitochondrial TCA cycle and urea cycle were observed, which showed significant dose- and time-dependencies on the GTPs treatment $(0-1.5 \% \mathrm{wt} / \mathrm{vol})$ [88].

\section{Benefits towards Immune-Related Disease}

GTPs can prevent many types of chronic diseases if regularly ingested in diet due to antioxidant, anticancer, anti-inflammatory, antiatherogenic, antidiabetic, antibacterial, and antiviral activities [89]. Moreover, GTPs exert protective effect on autoimmune diseases $[89,90]$.

\subsection{Benefits in Autoimmune Diseases}

Besides genetic or acquired defects in immune tolerance or immune regulatory pathways, molecular mimicry to viral or bacterial proteins and impaired clearance of apoptotic cell materials are all the mechanisms of autoimmunity. Therefore, autoimmunity might be mostly due to copious production of autoantibodies and autoreactive cells. The autoimmune diseases could be classified into systemic and organ specific [91]. Autoimmune disorders may be caused by multiple interactions predisposition, and environmental triggers also contribute a lot to the autoimmune diseases [91,92]. GTPs have showed significantly therapeutic potential in a variety of autoimmune diseases.

Sjogren's syndrome (SS), a relatively common autoimmunedisease, is characterized by inflammatory cell infiltration and loss of function of the lacrimal and salivary glands, which will result in ocular and oral health problems [92]. Selective inhibition of glandcell apoptosis, autoantigen expression, and production of pro-inflammatory cytokines are the three potential strategies for ameliorating SS [92]. Glandular cells may be important in initiating and sustaining SS, and the T-cell-mediated cytotoxicity and autoantibodies are also critical in the loss of gland function. Moreover, glandular epithelial cells contribute a lot to autoimmune process through secreting pro-inflammatory cytokines [91]. Aberrant expression and translocation of nuclear auto-antigens onto acinarcell membrane during apoptosis occurred, where they will be exposed to APCs (macrophages and dendritic cells) [93]. Furthermore, the auto-antigens redistributed in glandular cells and formed apoptotic bodies and blebs, around which autoantigen proteins (SS-A/Ro, SS-B/La, Ku, PARP, fodrin, golgins and NuMA) were clustered as subcellular structures [94]. The structural changes in auto-antigens may also contribute to the altered configuration of autoantigencluster, resulting in autoimmune response [94]. Naturally occurring phytochemicals in plant could be used in treating SS-associated disorders, such as GTPs, which could reduce the lymphocytic infiltration of submandibular gland in non-obese diabetic (NOD) mouse model for SS [95]. EGCG (0.2\% consumption) protected NOD mouse submandibular glands from autoimmune-induced inflammation through reducing lymphocyte infiltration in the salivary glands during disease advancing stages, inhibiting apoptotic activity within 
the lymphocytic infiltrates, decreasing levels of serum total anti-nuclear antibody, and suppressing the expression of cell nuclear proliferation markers, such as proliferating cell nuclear antigen (PCNA) and Ki-67 [92].

Compared to a water-treated experimental autoimmune uveoretinitis (EAU) murine model, GTE attenuated clinical manifestations of uveitis, increased retinal-choroidal thicknesses (RCT) $(1.100 \pm 0.013$ times vs1.005 \pm 0.012 times, $P<0.001)$ and retinal vessel dilation (308.9 \pm 6.189 units vs 240.8 units, $P<0.001)$ in a dose-dependent manner [96]. EGCG could also partially alleviate uveitic phenotypes and recover visualfunction in the murine model of EAU [96]. The treatment of GTE and its major component EGCG upregulated Th-17 associated pro-inflammatory genes, such as IL-1 $\beta$, IL-6, IL-17A, and TNF- $\alpha$ [96]. GTE consumption serves as a potent therapeutic agent and a food supplement to develop alternative treatments against autoimmune uveitis [96].

\subsection{Benefits in Cutaneousimmunity}

UV light could affect skin biology and immune system, and lead to immunosuppression, premature aging, oxidative stress, and even carcinogenesis [1]. Immunosuppression induced by solar UV radiation (UVR) is a risk factor for melanoma and nonmelanoma skin cancers, which could potentially allow dysplastic cells being undetected and developing to neoplasms [97]. Notably, UV-induced DNA damage, particularly in terms of the formation of cyclobutane pyrimidine dimers (CPD), serves as critical molecular triggers for UV-induced immunosuppression [97]. As a 70-kDa heterodimer, IL-12 could induce Th1 responses and repair UV induced DNA damage [97]. The prevention of UVR induced immunosuppression by IL-12 depended on DNA repair and the induction of nucleotide excision repair enzymes [97]. UV radiation could mediate inflammatory and immunological reactions through activation of receptors, induction of DNA/RNA damage, and production of ROS [98]. UVR could activate multiple signaling cascades, including p38 MAPK, Jun $\mathrm{N}$-terminal kinase, extracellular signal-regulated kinase $1 / 2$, and NF- $\mathrm{KB}$ pathways in skin cells [98].

Human skin could be divided into epidermal, dermal, and hypodermal layers. In particular, epidermis consists of five layers, including stratum basale, stratum spinosum, stratum granulosum, stratum lucidum, and stratum corneum. Stratum basale, the innermost layer of epidermis, contains rapidly proliferating and differentiating keratinocytes, Merkel cells, and melanocytes. The stratum spinosum layer contains Langerhans cells, which serve as part of the immune system [98]. After UV exposure, an early inflammatory event soon takes place, which is characteristic by erythema and redness due to vasodilation of cutaneous blood vessels [98]. UV-induced TNF- $\alpha$ could diminish antigen presentation, reduce immunosurveillance, and initiate immunosuppression [98].

In mice fed with purified GTE, dose-dependent decrease in UVR-induced immunosuppression was observed, which were performed through contact hypersensitivity response (CHR) to 2,4-dinitrofluorobenzene [29]. Furthermore, the decrease in immunosuppression lasted 4 weeks, even after the resumption of a normal liquid diet [29]. In UV-irradiated mice, GTPs could reduce the migration of CPD positive cells to lymph nodes and improve nucleotide-excision repair mechanisms [29]. In human and animal studies, GTPs show significant protective effects against UV-induced skin damage and immunosuppression [1]. In keratinocytes cells exposed to UV radiation, IL-12 could enhance the NER enzyme activity [99]. DNA repair by topically applied EGCG might be through an IL12-dependent mechanism [97]. Topical application of EGCG could effectively prevent UV-induced immunosuppression in rice through IL-12-dependent DNA repair, showing chemopreventive activity in prevention of photocarcinogenesis [97]. In particular, EGCG reduced number of CPDs+ cells and the migration of CPD+ APCs from skin to draining lymph nodes [97]. EGCG could prevent UV-induced immunosuppression by enhancing the levels of IL-12 [97]. Oral GrTP significantly delayed pathogenic leukocyte entry into skin following UV-B treatment [28]. 


\subsection{Benefits towards Obesity-Related Immune Disease}

Obesity is a major public health problem and global epidemic associating with comorbidities, such as diabetes, dyslipidemia, hypertension, cardiovascular diseases, and some cancers [100-102]. Strong relationship existed between adipose tissue and immune cells, as pro-inflammatory cytokines could not only increase free fatty acid (FFA) levels, but also induce ROS production [102]. Moreover, pro-inflammatory cytokines contributed a lot to the pro-inflammatory microenvironment in obesity and promoted activation and infiltration of immune cells into adipose tissue [102]. In obesity with high levels of hormones and nutrients, chronic low-grade inflammation state often present systemically or partially within the white adipose tissue (WAT) [103]. In particular, adipose tissue inflammation play important role in pathogenesis of diabetes. The energy-rich environment in obesity could damage immune cells present in blood stream and peripheral tissues [104]. Due to over-activation of immune cells, obese individuals are more subject to chronic inflammatory diseases, which would further destroy the functionality of immune cells and cause certain inflammatory response [105]. The increase in pro-inflammatory cytokines (IL-6, IL-1 $\beta$, and TNF- $\alpha$ ) and leptin released by adipocytes would drive lymphocytes to a Th1 phenotype in WAT [89]. Obesity often provides danger signals mimicking bacterial infection, which will drive a shift in M1 macrophages, CD8+, and CD4+ to Th1, Th2, and Th17, respectively. On the contrast, regulatory $\mathrm{T}$ cell (Treg) antiinflammatory lymphocyte numbers are decreased, which could prevent WAT inflammation and insulin resistance [106].

Significant immunomodulatory effects of GTPs under obese conditions have been observed, which were performed through recovering $\mathrm{H}_{2} \mathrm{O}_{2}$ and $\mathrm{HOCl}$ production, as well as reducing the levels of inflammatory cytokines [102]. In obese rats, GTPs could improve neutrophil function through increasing migration capacity of neutrophil, enhancing MPO activity, reducing catalase, increasing GSH/GSSG ratio, elevating production of $\mathrm{H}_{2} \mathrm{O}_{2}, \mathrm{HOCl}$ and $\mathrm{O}_{2}{ }^{-}$, as well as decreasing expression of TNF- $\alpha$, IL-6, TLR4, IkK, CD11b [102]. In Male Wistar rats, GTPs could reduce ROS production, improve redox status, reduce production of pro-inflammatory IL-2, IL-6, IL-1 $\beta$, TNF- $\alpha$ cytokines, elevate exoression of Foxp3, IRF4, and IL-10, and inhibit expression of TLR4 [89]. In obese rats, GTPs could decrease cell proliferation, and drive lymphocytes to a more anti-inflammatory than pro-inflammatory microenvironment [89]. GTPs reduced the contents of triacylglycerol, total cholesterol, and low-density lipoprotein cholesterol, as well as inhibited body andhepatic fat accumulation $[107,108]$. In juvenile black carp Mylopharyngodon piceus, GTPs $(500 \mathrm{mg} / \mathrm{kg}$ ) significantly reduced the HDL-C and LDL-C [80]. EGCG could limit lipid absorption and even lower plasma lipid levels in rats [109].

TLR4 plays critical roles in innate immunity through inducing inflammatory cytokine, and abnormal activation of TLR4 could induce obesity-induced inflammation [110]. As a 67-kDa laminin receptor, EGCG3"Me could suppress TLR4 expression via upregulating E3 ubiquitin-protein ring finger protein 216 (RNF216), and cyclic GMP played important roles in this process (Figure 1) [110]. Moreover, EGCG3"Me could significantly attenuate TLR4 expression in adipose tissue, inhibit high-fat/high-sucrose (HF/HS)-induced upregulation of TNF- $\alpha$ in adipose tissue, and increase the serum monocyte chemoattractant protein$1[110]$.

\section{Problems and Prospects}

Innate immunity and its molecular targets play important roles in the inflammatory response and protection against pathogens. The eukaryotic NF- $\mathrm{kB}$ transcription factors are critically involved in inflammation [36,59]. Interestingly, TLRs are expressed not only on immune cells but also on tumor cells constitutively or inducibly, thus natural products provide a means of dual targeting to combat diseases. Green tea is one of the most popular beverages around the world [22]. Epidemiological studies have suggested that the consumption of green tea is associated with reduced risk of some cancers, cardiovascular diseases, infections, and immunoregulation [111]. Green tea is rich in antioxidants that are useful to prevent onset and severity of arthritis [53,60]. In particular, GTPs possess 
significantly anti-inflammatory properties and are effective in inhibiting autoimmune diseases. Dietary GTPs could enhance immune responses to alleviate oxidative stress and damage caused by ammonia, showing potentials as a preventive or therapeutic measure in ammonia-exposed fish [55]. The increased levels of glutathione area critical mechanism underlying the beneficial effects of GTPs against some inflammatory disorders, and other mechanisms may also have a significant contribution. GTPs could not only divert immune types, but also reduce the burden of $\mathrm{T}$ lymphocytes under oxidative stress [36]. The great potential of GTPs to stimulate Th immune response against exogenous antigens makes them ideal as vaccines against pathogens and cancer cells. Oral therapy with GTPs could effectively prolong transplant survival and inhibit transplant-reactive $\mathrm{T}$ cell function in vivo, but the mechanisms need to be further discussed.

EGCG and ECG, the most abundant polyphenolic compound, possess effectively hepatic- and immune-protective properties against restraint stress through the combination of anti-oxidant, anti-inflammatory, and immunomodulatory activities [112]. EGCG could significantly reduce the release of stress hormones, which weak the restraint stress response [112]. Moreover, EGCG exerted neuroprotective effects in MPTP-induced PD mice model through modulating peripheral immune response, as EGCG treatment could restore the movement behavior of mice impaired by MPTP, and effectively protect tyrosine hydroxylase-positive cells in substantia nigra pars compacta region [42]. Accessory cells (mainly macrophages and DC) play critical roles in facilitating T cell activation and consequent proliferation, but EGCG could affect the function of accessory cells present in total splenocytes [41]. In restraint-challenged mice, EGCG $(10-40 \mathrm{mg} / \mathrm{kg})$ could significantly weak restraint stress response via preventing the release of $\mathrm{H}_{2} \mathrm{O}_{2}, \mathrm{NOS}$ and 8-isoprostane, reducing the levels of IL-1 $\beta$, IL-2 and IL-6, normalizing the level of cytochrome P450 (CYP450) 1A2, 2D22, 2E1 and 3A11, relieving the inhibition status of T cells subsets in serum and IgA in BALF, as well as improving hepatic damage through decreasing the serum levels of alanine aminotransaminase (ALT) and aspartate transaminase (AST) [112]. EGCG could significantly delay the onset of autoimmune diabetes and effectively protect salivary gland cells from autoimmune-induced damage at multiple levels, inferring that EGCG could be used to delay and manage SS-like autoimmune disorders. In addition, EGCG could inhibit NF-kB activation, activator of transcription 1 (STAT1)-dependent cellular events, $\mathrm{T}$ cell proliferation, and cytokine production $[33,40]$. Moreover, EGCG could interfere with maturation and functions of DCs, as well as induce Treg differentiation $[30,113]$. In particular, the phenol rings of EGCG and ECG, comprising phenyl and hydroxyl group structures, possess significant anti-inflammatory, immunomodulatory, and antioxidant properties [90]. Oral consumption of EGCG could protect secretory cells against autoimmune-induced damage and sustain cellular function in secretory glands via preventing cells from signals for proliferation or apoptosis.

Although the association between natural products and immunity is well established and immune-related therapeutic potential cannot be underestimated, the exact molecular pathways and cellular mechanisms of immunomodulatory effects of GTPs are not fully understood. As a potent antioxidant to scavenge cytotoxic ROS, little is known about how GTPs protect immune cells and modulate immune response to oxidative stress in farm animals, as well as the precise mechanisms for the multi-level protection by EGCG. However, adverse effects of oral consumption of GTPs have been demonstrated in several studies [114]. Thus far, the effects of EGCG on T cell-associated functions have been mostly studied in specific disease animal models in vivo, but few were performed on healthy hosts [115-119]. The effect of GTPs towards transplant-reactive T cell immunity suggest that oral intake of green tea could serve as an effective adjunctive therapy to prevent transplant rejection in humans. However, further studies deeply evaluating the immunosuppressive actions of GTPs are beneficial for clinical trials aimed at inhibiting $\mathrm{T}$ cell immune responses directed at transplant antigens in humans. The concentration of polyphenols present in crude plant preparations could only exert an adjuvant effect for a short period, therefore high dose is needed for sustained activity. 
Compared with individual compounds, green tea extracts showed more great healthpromoting potential in due to the synergistic effects of different compounds. Up to now, great efforts have been made both in vitro and in vivo, but the accurate mechanisms are still unclear. Therefore, more carefully-designed studies are needed to deeply elucidate the immune-potentiating properties towards cellular and humoral immune responses. Moreover, directions involve clarifying the precise action mechanisms of green tea polyphenols, the optimal therapeutic doses, duration of treatment, and effects in both in vitro and in vivo model systems, especially in the setting of inflammatory diseases, are also needed to be performed. Whether or not GTPs act on TLRs through covalent or non-covalent binding needs to be deeply clarified. Due to potential safety profiles and immunomodulatory effect, green tea might provide a new source for chemopreventive or therapeutic agents for various chronic diseases.

Author Contributions: Conceptualization, S.W. and S.L.; writing-original draft preparation, S.W. and Z.L.; writing - review and editing, Y.M., Y.L., and C.-C.L.; visualization, J.Z.; supervision, C.-T.H. and S.L.; funding acquisition, S.L. All authors have read and agreed to the published version of the manuscript.

Funding: This research reported in this paper are funded by grant from Hubei Province, China (2019ABA100), Open fund of Hubei Key Laboratory of Economic Forest Germplasm Improvement and Resources Comprehensive Utilization (201932103), and fund from Assessment and Comprehensive Utilization of Characteristic Biological resources in Dabie Mountains (4022019006).

Institutional Review Board Statement: Not applicable.

Informed Consent Statement: Not applicable.

Data Availability Statement: Not applicable.

Conflicts of Interest: The authors declare no conflict of interest.

$\begin{array}{ll}\text { Abbreviations } & \\ \text { Ag } & \text { Antigen } \\ \text { ALT } & \text { Alanine aminotransaminase } \\ \text { APCs } & \text { Antigen-presenting cells } \\ \text { AST } & \text { Aspartate transaminase } \\ \text { BSA } & \text { Bovine serum albumin } \\ \text { CCL20 } & \text { CC chemokine ligand-20 } \\ \text { CHR } & \text { Contact hypersensitivity response } \\ \text { CPD } & \text { Cyclobutanepyrimidine dimers } \\ \text { COX } & \text { Cyclooxygenase } \\ \text { Con A } & \text { Concanavalin A } \\ \text { CYP450 } & \text { Cytochrome P450 } \\ \text { DCs } & \text { Dendritic cells } \\ \text { EAU } & \text { Experimental autoimmune uveoretinitis } \\ \text { EGCG } & (-) \text {-Epigallocatechin-3-gallate } \\ \text { EGCG3"Me } & (-) \text {-Epigallocatechin-3-O-(3-O-methyl) gallate } \\ \text { ECG } & (-) \text {-Epicatechin gallate } \\ \text { ERK } & \text { External signal-regulated kinases } \\ \text { FFA } & \text { Free fatty acid } \\ \text { GOT } & \text { Glutamic oxalacetic transaminase } \\ \text { GTE } & \text { Green tea extracts } \\ \text { GTPs } & \text { Green tea polyphenols } \\ \text { GSH } & \text { Glutathione } \\ \text { GSH-Pox } & \text { Glutathione peroxidase } \\ \end{array}$




\begin{tabular}{|c|c|}
\hline HESI & Heated electrospray ionization \\
\hline HDPC cells & Human dental pulp-derived cells \\
\hline HDL-C & High-density lipoprotein cholesterol \\
\hline HGFs & Human gingival fibroblasts \\
\hline HILIC & Hydrophilic interaction liquid chromatography \\
\hline HO-1 & Heme oxygenase- 1 \\
\hline $\mathrm{HF} / \mathrm{HS}$ & High-fat/high-sucrose \\
\hline Ig & Immunoglobulin \\
\hline $\operatorname{IgM}$ & Immunoglobulin $\mathrm{M}$ \\
\hline $\mathrm{IFN} \gamma$ & Interferon gamma \\
\hline IL & Interleukin \\
\hline $\mathrm{IKK} \beta$ & IkB kinase \\
\hline iNOS & Inducible nitric oxide synthetase \\
\hline IRAKs & IL-1R associated kinases \\
\hline LC-MS & Liquid chromatography mass spectrometry \\
\hline LDL-C & Low-density lipoprotein cholesterol \\
\hline LOX & Lipoxygenase \\
\hline LPS & Lipopolysacharrides \\
\hline LTs & Leukotrienes \\
\hline LTT & T lymphocyte transformation \\
\hline MAPK & Mitogen-activated protein kinase \\
\hline MDA & Malondialdehyde \\
\hline MHC & Major histocompatibility complex \\
\hline MMP & Matrix metalloproteinase \\
\hline MPTP & 1-Methyl-4-phenyl-1,2,3,6-tetrahydropyridine \\
\hline MSU & Monosodium urate \\
\hline MS & Multiple sclerosis \\
\hline MyD88 & Myeloid differentiation primary response gene 88 \\
\hline NF- $\kappa \mathrm{B}$ & Nuclear factor $-\kappa B$ \\
\hline NLRP3 & NOD-like receptor protein 3 \\
\hline $\mathrm{Nk}$ & Natural killer cells \\
\hline No & Nitric oxide \\
\hline Nod & Non-obese diabetic \\
\hline Pamps & Pathogen-associated molecular patterns \\
\hline PARP & Poly(ADP-ribose) polymerase \\
\hline PCNA & Proliferating cell nuclear antigen \\
\hline PD & Parkinson's disease \\
\hline p-ERK & Phosphorylated extracellular signal-regulated kinase \\
\hline PGE2 & Prostaglandin E2 \\
\hline PFC & Plaque-forming cell \\
\hline PGs & Prostaglandins \\
\hline PI3K & Phosphatidylinositol-3-kinase \\
\hline p-JNK & Phosphorylated c-Jun N-terminal \\
\hline PPAR $\gamma$ & Peroxisome proliferator-activated receptor gamma \\
\hline PRRs & Pattern-recognition receptors \\
\hline RA & Rheumatoid arthritis \\
\hline $\mathrm{RCT}$ & Retinal-choroidal thicknesses \\
\hline RNF216 & Ringfinger protein 216 \\
\hline ROS & Reactive oxygen species \\
\hline SEB & Staphylococcus aureus enterotoxin B \\
\hline SRBCs & Sheep red blood cells \\
\hline SS & Sjogren's syndrome \\
\hline SOD & Serum superoxide dismutase \\
\hline ssRNA & Single stranded RNA \\
\hline TCA & Tricarboxylic acid \\
\hline
\end{tabular}




$\begin{array}{ll}\text { Th } & \text { Thelper cell } \\ \text { TFG } & \text { Theaflavin digallate } \\ \text { TG } & \text { Triglyceride } \\ \text { TIR } & \text { Toll/interleukin } 1 \text { receptor } \\ \text { TLR } & \text { Toll-like receptor } \\ \text { Treg } & \text { Regulatory T cell } \\ \text { UV } & \text { Ultraviolet } \\ \text { UVR } & \text { Ultraviolet radiation } \\ \text { WSSV } & \text { White spot syndrome virus } \\ \text { WAT } & \text { White adipose tissue }\end{array}$

\section{References}

1. Yoshida, S.H.; Gershwin, M.E. Immunity, infection, and nasal disease. Clin. Rev. Allerg. Immunol. 1998, 16, 3-24. [CrossRef] [PubMed]

2. Patricia, O.W.; Heather, T.; Elma, B. Protective mechanisms of green tea polyphenols in skin. Oxid. Med. Cell. Longev. 2012, 2012, 560682.

3. Mogensen, T.H. Pathogen recognition and inflammatory signaling in innate immune defenses. Clin. Microbiol. Rev. 2009, 22, 240-273. [CrossRef] [PubMed]

4. Akira, S.; Uematsu, S.; Takeuchi, O. Pathogen recognition and innate immunity. Cell 2006, 124, 783-801. [CrossRef] [PubMed]

5. Chen, L.; Yu, J. Modulation of Toll-like receptor signaling in innate immunity by natural products. Int. Immunopharmacol. 2016, 37, 65-70. [CrossRef]

6. He, S.; Chu, J.; Wu, L.C.; Mao, H.; Peng, Y.; Alvarez-Breckenridge, C.A.; Hughes, T.; Wei, M.; Zhang, J.; Yuan, S.; et al. MicroRNAs activate natural killer cells through Toll-like receptor signaling. Blood 2013, 121, 4663-4671. [CrossRef] [PubMed]

7. Qiu, F.; Maniar, A.; Diaz, M.Q.; Chapoval, A.I.; Medvedev, A.E. Activation of cytokineproducing and antitumor activities of natural killer cells and macrophages by engagement of Toll-like and NOD-like receptors. Innate Immun. 2011, 17, 375-387. [CrossRef]

8. Sallusto, F.; Lanzavecchia, A. The instructive role of dendritic cells on T-cell responses. Arthritis Res. 2002, 4 (Suppl. S3), S127-S132. [CrossRef]

9. Kabelitz, D. Expression and function of Toll-like receptors in T lymphocytes. Curr. Opin. Immunol. 2007, 19, 39-45. [CrossRef]

10. Gerondakis, S.; Grumont, R.J.; Banerjee, A. Regulating B-cell activation and survival in response to TLR signals. Immunol. Cell Biol. 2007, 85, 471-475. [CrossRef]

11. Hennessy, E.J.; Parker, A.E.; O'Neill, L.A. Targeting Toll-like receptors: Emerging therapeutics? Nat. Rev. Drug Discov. 2010, 9 , 293-307. [CrossRef]

12. Tsai, C.C.; Lin, C.R.; Tsai, H.Y.; Chen, C.J.; Li, W.T.; Yu, H.M.; Ke, Y.Y.; Hsieh, W.Y.; Chang, C.C.Y.; Wu, C.Y.; et al. The immunologically active oligosaccharides isolated from wheat grass modulate monocytes via Tolllike receptor-2 signaling. J. Biol. Chem. 2013, 288, 17689-17697. [CrossRef]

13. Vaure, C.; Liu, Y. A comparative review of toll-like receptor 4 expression and functionality in different animal species. Front. Immunol. 2014, 5, 316. [CrossRef]

14. O'Neill, L.A.; Golenbock, D.; Bowie, A.G. The history of Toll-like receptors- redefining innate immunity. Nat. Rev. Immunol. 2013, 13, 453-460. [CrossRef] [PubMed]

15. Shaw, A.C.; Panda, A.; Joshi, S.R.; Qian, F.; Allore, H.G.; Montgomery, R.R. Dysregulation of human Toll-like receptor function in aging. Ageing Res. Rev. 2011, 10, 346-353. [CrossRef] [PubMed]

16. Li, M.; Zhou, Y.; Feng, G.; Su, S.B. The critical role of Toll-like receptor signaling pathways in the induction and progression of autoimmune diseases. Curr. Mol. Med. 2009, 9, 365-374. [CrossRef] [PubMed]

17. Lee, J.Y.; Hwang, D.H. The modulation of inflammatory gene expression by lipids: Mediation through Toll-like receptors. Mol. Cell 2006, 21, 174-185.

18. Dias, D.A.; Urban, S.; Roessner, U. A historical overview of natural products in drug discovery. Metabolites 2012, 2, 303-336. [CrossRef] [PubMed]

19. Haddad, P.S.; Azar, G.A.; Groom, S.; Boivin, M. Natural health products, modulation of immune function and prevention of chronic diseases. Evid. Based Complement. Alternat. Med. 2005, 2, 513-520.

20. Kingston, D.G. Modern natural products drug discovery and its relevance to biodiversity conservation. J. Nat. Prod. 2011, 74, 496-511. [CrossRef]

21. Pan, M.H.; Chiou, Y.S.; Wang, Y.J.; Ho, C.T.; Lin, J.K. Multistage carcinogenesis process as molecular targets in cancer chemoprevention by epicatechin-3-gallate. Food Funct. 2011, 2, 101. [CrossRef]

22. Zhang, X.; Li, J.; Li, Y.; Liu, Z.; Lin, Y.; Huang, J. Anti-melanogenic effects of epigallocatechin-3-gallate (EGCG), epicatechin3-gallate (ECG) and gallocatechin-3-gallate (GCG) via down-regulation of cAMP/CREB/MITF signaling pathway in B16F10 melanoma cells. Fitoterapia 2020, 145, 104634. [CrossRef] 
23. Way, T.D.; Lin, H.Y.; Kuo, D.H.; Tsai, S.J.; Shieh, J.C.; Wu, J.C.; Lee, M.R.; Lin, J.K. Pu-erh tea attenuates hyperlipogenesis and induces hepatoma cells growth arrest through activating AMP-activated protein kinase (AMPK) in human HepG2 cells. J. Agric. Food Chem. 2009, 57, 5257. [CrossRef]

24. Wilasrusmee, C.; Kittur, S.; Siddiqui, J.; Bruch, D.; Wilasrusmee, S.; Kittur, D.S. In vitro immunomodulatory effects of ten commonly used herbs on murine lymphocytes. J. Altern. Complem. Med. 2002, 8, 467-475. [CrossRef] [PubMed]

25. Braun, D.P.; Johnson, D.M.; Katsantonis, N.G.; Bhesaniya, K.; Staren, E.D. Apoptotic and immunomodulatory effects of green tea extracts (GTE) on chemoresistant human tumor cells. J. Clin. Oncol. 2009, 27 (Suppl. S15), e22101. [CrossRef]

26. Youn, H.S.; Lee, J.Y.; Saitoh, S.I.; Miyake, K.; Kang, K.W.; Yong, J.C.; Hwang, D.H. Suppression of MyD88- and TRIF-dependent signaling pathways of Toll-like receptor by (-)-epigallocatechin-3-gallate, a polyphenol component of green tea. Biochem. Pharmacol. 2006, 72, 850-859. [CrossRef]

27. Watson, J.L.; Vicario, M.; Wang, A.; Moreto, M.; McKay, D.M. Immune cell activation and subsequent epithelial dysfunction by Staphylococcus enterotoxin B is attenuated by the green tea polyphenol (-)-epigallocatechin gallate. Cell Immunol. 2005, 237, 7-16. [CrossRef] [PubMed]

28. Katiyar, S.K.; Mukhtar, H. Green tea polyphenol (-)-epigallocatechin-3-gallate treatment to mouse skin prevents UVB-induced infiltration of leukocytes, depletion of antigen-presenting cells, and oxidative stress. J. Leukoc. Biol. 2001, 69, 719-726. [PubMed]

29. Katiyar, S.K.; Vaid, M.; Van Steeg, H.; Meeran, S.M. Green tea polyphenols prevent UV-induced immunosuppression by rapid repair of DNA damage and enhancement of nucleotide excision repair genes. Cancer Prev. Res. 2010, 3, 179-189. [CrossRef]

30. Ahn, S.C.; Kim, G.Y.; Kim, J.H.; Baik, S.W.; Han, M.K.; Lee, H.J.; Moon, D.O.; Lee, C.M.; Kang, J.H.; Kim, B.H. Epigallocatechin-3gallate, constituent of green tea, suppresses the LPS-induced phenotypic and functional maturation of murine dendritic cells through inhibition of mitogen-activated protein kinases and NF-kB. Biochem. Biophys. Res. Commun. 2004, 313, 148-155. [CrossRef]

31. Yoneyama, S.; Kawai, K.; Tsuno, N.H.; Okaji, Y.; Asakage, M.; Tsuchiya, T.; Yamada, J.; Sunami, E.; Osada, T.; Kitayama, J. Epigallocatechin gallate affects human dendritic cell differentiation and maturation. J. Allergy Clin. Immun. 2008, 121, 209-214. [CrossRef]

32. Wang, Z.; Sun, B.; Zhu, F. Epigallocatechin-3-gallate protects Kuruma shrimp Marsupeneaus japonicus from white spot syndrome virus and Vibrio alginolyticus. Fish Shellfish Immun. 2018, 78, 1-9. [CrossRef]

33. Varilek, G.W.; Yang, F.; Lee, E.Y.; de Villiers, W.J.; Zhong, J.; Oz, H.S.; Westberry, K.F.; McClain, C.J. Green tea polyphenol extract attenuates inflammation in interleukin-2-deficient mice, a model of autoimmunity. J. Nutr. 2001, 131, 2034-2039. [CrossRef] [PubMed]

34. Yang, F.; Oz, H.S.; Barve, S.; de Villiers, W.J.; McClain, C.J.; Varilek, G.W. The green tea polyphenol (-)-epigallocatechin-3-gallate blocks nuclear factor- $\mathrm{kB}$ activation by inhibiting I кB kinase activity in the intestinal epithelial cell line IEC. Mol. Pharmacol. 2001, 60, 528-533. [PubMed]

35. Tedeschi, E.; Suzuki, H.; Menegazzi, M. Antiinflammatory action of EGCG, the main component of green tea, through STAT-1 inhibition. Ann. N. Y. Acad. Sci. 2002, 973, 435-437. [CrossRef] [PubMed]

36. Deng, Q.; Xu, J.; Yu, B.; He, J.; Zhang, K.; Ding, X.; Chen, D. Effect of dietary tea polyphenols on growth performance and cell mediated immune response of post-weaning piglets under oxidative stress. Arch. Anim. Nutr. 2010, 64, 12-21. [CrossRef] [PubMed]

37. Lee, C.Y.J.; Wan, J.M.F. Vitamin E supplementation improves cell-mediated immunity and oxidative stress of Asian men and women. J. Nutr. 2000, 130, 2932-2937. [CrossRef] [PubMed]

38. Bayer, J.; Gomer, A.; Demir, Y.; Amano, H.; Kish, D.D.; Fairchild, R.; Heeger, P.S. Effects of green tea polyphenols on murine transplant-reactive T cell immunity. Clin. Immunol. 2004, 110, 100-108. [CrossRef]

39. Gringhuis, S.I.; Papendrecht-van der Voort, E.A.M.; Leow, A.; Levarht, E.W.N.; Breedveld, F.C.; Verweij, C.L. Effect of redox balance alterations on cellular localization of LAT and downstream T-cell receptor signalling pathways. Mol. Cell Biol. 2002, 22, 400-411. [CrossRef]

40. Wu, D.; Guo, Z.; Ren, Z.; Guo, W.; Meydani, S.N. Green tea EGCG suppresses T cell proliferation through impairment of IL-2/IL-2 receptor signaling. Free Radic. Biol. Med. 2009, 47, 636-643. [CrossRef]

41. Pae, M.; Ren, Z.; Meydani, M.; Shang, F.; Meydani, S.N.; Wu, D. Epigallocatechin-3- gallate directly suppresses T cell proliferation through impaired IL-2 utilization and cell cycle progression. J. Nutr. 2010, 140, 1509-1515. [CrossRef]

42. Zhou, T.; Zhu, M.; Liang, Z. (-)-Epigallocatechin-3-gallate modulates peripheral immunity in the MPTP-induced mouse model of Parkinson's disease. Mol. Med. Rep. 2018, 17, 4883-4888. [CrossRef] [PubMed]

43. Huang, S.C.; Kao, Y.H.; Shih, S.F.; Tsai, M.C.; Lin, C.S.; Chen, L.W.; Chuang, Y.P.; Tsui, P.F.; Ho, L.J.; Lai, J.H.; et al. Epigallocatechin3-gallate exhibits immunomodulatory effects in human primary T cells. Biochem. Biophys. Res. Commun. 2021, 550, 70-76. [CrossRef] [PubMed]

44. Demeule, M.; Brossard, M.; Pagé, M.; Gingras, D.; Béliveau, R. Matrix metalloproteinase inhibition by green tea catechins. Biochim. Biophys. Acta 2000, 1478, 51. [CrossRef]

45. Corbel, M.; Belleguic, C.; Boichot, E.; Lagente, V. Involvement of gelatinases (MMP-2 and MMP-9) in the development of airway inflammation and pulmonary fibrosis. Cell Biol. Toxicol. 2002, 18, 51. [CrossRef] [PubMed]

46. Hofbauer, R.; Frass, M.; Gmeiner, B.; Handler, S.; Speiser, W.; Kapiotis, S. The green tea extract epigallocatechin gallate is able to reduce neutrophil transmigration through monolayers of endothelial cells. Wiener Klinische Wochenschrift 1999, 111, 278. [PubMed] 
47. Nguyen, T.; Payan, B.; Zambrano, A.; Du, Y.; Bondesson, M.; Mohan, C. Epigallocatechin-3-gallate suppresses neutrophil migration speed in a transgenic zebrafish model accompanied by reduced inflammatory mediators. J. Inflamm. Res. 2019, 12, 231-239. [CrossRef]

48. Donà, M.; Dell'Aica, I.; Calabrese, F.; Benelli, R.; Morini, M.; Albini, A.; Garbisa, S. Neutrophil restraint by green tea: Inhibition of inflammation, associated angiogenesis, and pulmonary fibrosis. J. Immunol. 2003, 170, 4335-4341. [CrossRef]

49. Yang, F.; de Villiers, W.J.S.; McClain, C.J.; Varilek, G.W. Green tea polyphenols block endotoxin-induced tumor necrosis factor production and lethality in a murine model. J. Nutr. 1998, 128, 2334-2340. [CrossRef]

50. Lin, Y.L.; Lin, J.K. (-)-Epigallocatechin-3-gallate blocks the induction of nitric oxide synthase by down-regulating lipopolysaccharide-induced activity of transcription factor nuclear factor-kB. Mol. Pharmacol. 1997, 52, 465-472. [CrossRef]

51. Zvetkova, E.; Wirleitner, B.; Tram, N.T.; Schennach, H.; Fuchs, D. Aqueous extracts of Crinum latifolium (L.) and Camellia sinensis show immunomodulatory properties in human peripheral blood mononuclear cells. Int. Immunopharmacol. 2001, 1, 2143-2150. [CrossRef]

52. Khan, A.; Ali, N.H.; Santercole, V.; Paglietti, B.; Rubino, S.; Kazmi, S.U.; Farooqui, A. Camellia sinensis mediated enhancement of humoral immunity to particulate and non-particulate Antigens. Phytother. Res. 2016, 30, 41-48. [CrossRef]

53. Haqqi, T.M.; Anthony, D.D.; Gupta, S.; Ahmad, N.; Lee, M.S.; Kumar, G.K.; Mukhtar, H. Prevention of collagen-induced arthritis in mice by a polyphenolic fraction from green tea. Proc. Natl. Acad. Sci. USA 1999, 96, 4524-4529. [CrossRef] [PubMed]

54. Hu, Z.Q.; Toda, M.; Okubo, S.; Hara, Y.; Shimamura, T. Mitogenic activity of (-) epigallocatechin gallate on B-cells and investigation of its structure function relationship. Int. J. Immunopharmacol. 1992, 14, 1399-1407. [PubMed]

55. Guo, H.; Lin, W.; Wang, L.; Zhang, D.; Wu, X.; Li, L.; Li, D.; Tang, R.; Yang, L.; Qiu, Y. The supplementation of dietary selenium yeast and green tea-derived polyphenols improves antioxidant capacity and immune response in juvenile Wuchang bream under ammonia stress. Aquac. Res. 2020, 51, 1-14. [CrossRef]

56. Majdalawieh, A.; Ro, H.S. Regulation of IкBalpha function and NF- $\kappa B$ signaling: AEBP1 is a novel proinflammatory mediator in macrophages. Mediat. Inflamm. 2010, 2010, 823821. [CrossRef] [PubMed]

57. Majdalawieh, A.F.; Fayyad, M.W. Immunomodulatory and anti-inflammatory action of Nigella sativa and thymoquinone: A comprehensive review. Int. Immunopharmacol. 2015, 28, 295-304. [CrossRef] [PubMed]

58. Van Ryn, J.; Trummlitz, G.; Pairet, M. COX-2 selectivity and inflammatory processes. Curr. Med. Chem. 2000, 7, $1145-1161$. [CrossRef]

59. Magee, P.; Pearson, S.; Whittingham-Dowda, J.; Allen, J.J. PPAR $\gamma$ as a molecular target of EPA anti-inflammatory activity during TNF- $\alpha$-impaired skeletal muscle cell differentiation. J. Nutr. Biochem. 2012, 23, 1440-1448. [CrossRef]

60. Kim, H.R.; Rajaiah, R.; Wu, Q.L.; Satpute, S.R.; Tan, M.T.; Simon, J.E.; Berman, B.M.; Moudgil, K.D. Green tea protects rats against autoimmune arthritis by modulating disease-related immune events. J. Nutr. 2008, 138, 2111-2116. [CrossRef]

61. Abboud, P.A.; Hake, P.W.; Burroughs, T.J.; Odoms, K.; O'Connor, M.; Mangeshkar, P.; Wong, H.R.; Zingarelli, B. Therapeutic effect of epigallocatechin-3-gallate in a mouse model of colitis. Eur. J. Pharmacol. 2008, 579, 411-417. [CrossRef] [PubMed]

62. Tsai, P.Y.; Ka, S.M.; Chang, J.M.; Chen, H.C.; Sui, H.A.; Li, C.Y.; Hua, K.F.; Chang, W.L.; Huang, J.J.; Yang, S.S.; et al. Epigallocatechin-3-gallte prevents lupus nephritis development in mice via enhancing the Nrf2 antioxidant pathway and inhibiting NLRP3 inflammasome activation. Free Radic. Biol. Med. 2011, 51, 744-754. [CrossRef] [PubMed]

63. Wang, J.; Ren, Z.; Xu, Y.; Xiao, S.; Meydani, S.N.; Wu, D. Epigallocatechin-3-gallate ameliorates experimental autoimmune encephalomyelitis by altering balance among CD4 ${ }^{+}$T-cell subsets. Am. J. Pathol. 2012, 180, 221-234. [CrossRef]

64. Hoshikawa, S.; Nakagawa, Y.; Ozaki, H.; Takahashi, Y.; Ito, S.; Yoshida, K.; Mori, K. Effects of green tea polyphenols on iodide-induced autoimmune thyroiditis in nonobese diabetic mice. Immunol. Invest. 2013, 42, 235-246. [CrossRef] [PubMed]

65. Wheeler, D.S.; Catravas, J.D.; Odoms, K.; Denenberg, A.; Malhotra, V.; Wong, H.R. Epigallocatechin-3-gallate, a green tea-derived polyphenol, inhibits IL-1b- dependent proinflammatory signal transduction in cultured respiratory epithelial cells. J. Nutr. 2004, 134, 1039-1044. [CrossRef]

66. Nakanishi, T.; Mukai, K.; Yumoto, H.; Hirao, K.; Hosokawa, Y.; Matsuo, T. Anti-inflammatory effect of catechin on cultured human dental pulp cells affected by bacteria-derived factors. Eur. J. Oral Sci. 2010, 118, 145-150. [CrossRef] [PubMed]

67. Nakanishi, T.; Mukai, K.; Hosokawa, Y.; Takegawa, D.; Matsuo, T. Catechins inhibit vascular endothelial growth factor production and cyclooxygenase-2 expression in human dental pulp cells. Int. Endod. J. 2015, 48, 277-282. [CrossRef] [PubMed]

68. el-Saadany, M.A.; Rawel, H.M.; Raila, J. Antioxidants modulate the IL-6 induced inhibition of negative acute-phase protein secretion in HepG2 cells. Cell Biochem. Funct. 2008, 26, 95-101. [CrossRef]

69. Hosokawa, Y.; Hosokawa, I.; Ozaki, K.; Nakanishi, T.; Nakae, H.; Matsuo, T. Catechins inhibit CCL20 production in IL-17Astimulated human jingival fibroblasts. Cell. Physiol. Biochem. 2009, 24, 391-396. [CrossRef]

70. Chiou, Y.S.; Huang, Q.R.; Ho, C.T. Directly interact with keap1 and lps is involved in the anti-inflammatory mechanisms of (-)-epicatechin-3-gallate in LPS- induced macrophages and endotoxemia. Free Radic. Biol. Med. 2016, 94, 1-16. [CrossRef]

71. Lee, H.E.; Yang, G.; Park, Y.B.; Kang, H.C.; Cho, Y.Y.; Lee, H.S.; Lee, J.Y. Epigallocatechin-3-gallate prevents acute gout by suppressing NLRP3 inflammasome activation and mitochondrial DNA Synthesis. Molecules 2019, 24, 2138. [CrossRef]

72. Gao, Z.; Han, Y.; Hu, Y.; Wu, X.; Wang, Y.; Zhang, X.; Fu, J.; Zou, X.; Zhang, J.; Chen, X.; et al. Targeting HO-1 by epigallocatechin3-gallate reduces contrast-induced renal injury via anti-oxidative stress and anti-inflammation pathways. PLoS ONE 2016, 11, e0149032. [CrossRef] 
73. Wang, D.X.; Gao, Q.; Wang, T.T.; Kan, Z.P.; Li, X.; Hu, L.Z.; Peng, C.Y.; Qian, F.; Wang, Y.; Granato, D. Green tea polyphenols and epigallocatechin-3-gallate protect against perfluorodecanoic acid induced liver damage and inflammation in mice by inhibiting NLRP3 inflammasome activation. Food Res. Int. 2020, 127, 108628. [CrossRef]

74. Dobmeyer, T.S.; Findhammer, S.; Dobmeyer, J.M.; Klein, S.A.; Raffel, B.; Hoelzer, D.; Helm, E.B.; Kabelitz, D.; Rossol, R. Ex vivo induction of apoptosis in lymphocytes is mediated by oxidative stress: Role for lymphocyte loss in HIV infection. Free Radic. Biol. Med. 1997, 22, 775-785. [CrossRef]

75. Sordillo, L.M.; Aitken, S.L. Impact of oxidative stress on the health and immune function of dairy cattle. Vet. Immunol. Immunopathol. 2009, 128, 104-109. [CrossRef] [PubMed]

76. Sklavos, M.M.; Tse, H.M.; Piganelli, J.D. Redox modulation inhibits CD8 T cell effector function. Free Radic. Biol. Med. 2008, 45, 1477-1486. [CrossRef] [PubMed]

77. Locatelli, F.; Canaud, B.; Eckardt, K.U.; Stenvinkel, P.; Wanner, C.; Zoccali, C. Oxidative stress in end-stage renal disease: An emerging threat to patient outcome. Nephrol. Dial. Transpl. 2003, 18, 1272-1280. [CrossRef] [PubMed]

78. Zhang, B.; Safa, R.; Rusciano, D.; Osborne, N.N. Epigallocatechin gallate, an active ingredient from green tea, attenuates damaging influences to the retina caused by ischemia/reperfusion. Brain Res. 2007, 1159, 40-53. [CrossRef] [PubMed]

79. Vidali, M.; Stewart, S.F.; Albano, E. Interplay between oxidative stress and immunity in the progression of alcohol-mediated liver injury. Trends Mol. Med. 2008, 14, 63-71. [CrossRef]

80. Zhong, L.; Hu, Y.; Hu, Y.; Li, J.; Tian, Y.; Chen, J.; Ai, Q.; Xiao, T. Effects of dietary tea polyphenols on growth, immunity and lipid metabolism of juvenile black carp Mylopharyngodon piceus. Aquac. Res. 2019, 51, 1-8. [CrossRef]

81. Burckhardt, I.C.; Gozal, D.; Dayyat, E.; Cheng, Y.; Li, R.C.; Row, B.W. Green tea catechin polyphenols attenuate behavioral and oxidative responses to intermittent hypoxia. Am. J. Resp. Crit. Care 2008, 177, 1135-1141. [CrossRef]

82. Mohd, F.; Mohammad, O.; Sandesh, C.; Sheikh, M.H.; Aamir, A. Mobilization of nuclear copper by green tea polyphenol epicatechin-3-gallate and subsequent prooxidant breakage of cellular DNA: Implications for cancer chemotherapy. Int. J. Mol. Sci. 2017, 18, 34 .

83. Axling, U.; Olsson, C.; Xu, J.; Fernandez, C.; Larsson, S.; Ström, K.; Ahrnè, S.; Holm, C.; Molin, G.; Berger, K. Green tea powder and Lactobacillus plantarum affect gut microbiota, lipid metabolism and inflammation in high-fat fed C57BL/6J mice. Nutr. Metab. 2012, 9, 105. [CrossRef]

84. Jin, J.S.; Touyama, M.; Hisada, T.; Benno, Y. Effects of green tea consumption on human fecal microbiota with special reference to Bifidobacterium species. Microbiol. Immunol. 2012, 11, 729-739. [CrossRef]

85. Dae-Bang, S.; Jeong, H.W.; Cho, D.; Lee, B.J.; Lee, J.H.; Choi, J.Y.; Il-Hong, B.; Sung-Joon, L. Fermented green tea extract alleviates obesity and related complications and alters gut microbiota composition in diet-induced obese mice. J. Med. Food 2015, 18, 549-556.

86. Liu, Z.; Chen, Z.; Guo, H.; He, D.; Zhao, H.; Wang, Z.; Zhang, W.; Liao, L.; Zhang, C.; Ni, L. The modulatory effect of infusions of green tea, oolong tea, and black tea on gut microbiota in high-fat-induced obese mice. Food Funct. 2016, 7, 4869-4879. [CrossRef] [PubMed]

87. Guo, X.; Cheng, M.; Zhang, X.; Cao, J.; Wu, Z.; Weng, P. Green tea polyphenols reduce obesity in high-fat diet-induced mice by modulating intestinal microbiota composition. Int. J. Food Sci. Tech. 2017, 52, 1723-1730. [CrossRef]

88. Zhou, J.; Tang, L.; Shen, C.L.; Wang, J.S. Green tea polyphenols boost gut-microbiota- dependent mitochondrial TCA and urea cycles in Sprague-Dawley rats. J. Nutr. Biochem. 2020, 81, 108395. [CrossRef] [PubMed]

89. Molina, N.; Bolin, A.P.; Otton, R. Green tea polyphenols change the profile of inflammatory cytokine release from lymphocytes of obese and lean rats and protect against oxidative damage. Int. Immunopharmacol. 2015, 28, 985-996. [CrossRef] [PubMed]

90. Wu, D.; Wang, J.; Pae, M.; Meydani, S.N. Green tea EGCG, T cells, and T cell- mediated autoimmune diseases. Mol. Aspects Med. 2012, 33, 107-118. [CrossRef] [PubMed]

91. Hayashi, Y.; Arakaki, R.; Ishimaru, N. Apoptosis and estrogen deficiency in primary Sjögren's syndrome. Curr. Opin. Rheumatol. 2004, 16, 522-526. [CrossRef]

92. Gillespie, K.; Kodani, I.; Dickinson, D.P.; Ogbureke, K.; Camba, A.M.; Wu, M.; Looney, S.; Chu, T.C.; Qin, H.; Bisch, F.; et al. Effects of oral consumption of the green tea polyphenol EGCG in a murine model for human Sjogren's syndrome, an autoimmune disease. Life Sci. 2008, 83, 581-588. [CrossRef]

93. Van Woerkom, J.M.; Geertzema, J.G.; Nikkels, P.G.; Kruize, A.A.; Smeenk, R.J.; Vroom, T.M. Expression of Ro/SS-A and La/SS-B determined by immunohistochemistry in healthy, inflamed and autoimmune diseased human tissues: A generalized phenomenon. Clin. Exp. Rheumatol. 2004, 22, 285-292.

94. Rosen, A.; Casciola-Rosen, L. Altered autoantigen structure in Sjögren's syndrome: Implications for the pathogenesis of autoimmune tissue damage. Crit. Rev. Oral Biol. Med. 2004, 15, 156-164. [CrossRef]

95. Hsu, S.; Dickinson, D.P.; Qin, H.; Borke, J.; Ogbureke, K.; Winger, J.N.; Walsh, D.S.; Bollag, W.B.; Stoppler, H.; Sharawy, M.; et al. Green tea polyphenols reduce autoimmune symptoms in a murine model for human Sjogren's syndrome and protect human salivary acinar cells from TNF-alpha- induced cytotoxicity. Autoimmunity 2007, 40, 138-147. [CrossRef] [PubMed]

96. Li, J.; Yip, Y.W.Y.; Ren, J.; Hui, W.K.; He, J.N.; Yu, Q.X.; Chu, K.O.; Ng, T.K.; Chan, S.O.; Pang, C.P.; et al. Green tea catechins alleviate autoimmune symptoms and visual impairment in a murine model for human chronic intraocular infammation by inhibiting Th17-associated pro-inflammatory gene expression. Sci. Rep. 2019, 9, 2301. [CrossRef] 
97. Meeran, S.M.; Mantena, S.K.; Katiyar, S.K. Prevention of ultraviolet radiation-induced immunosuppression by (-)epigallocatechin-3-gallate in mice is mediated through interleukin 12-dependent DNA repair. Clin. Cancer Res. 2006, 12, 2272-2280. [CrossRef] [PubMed]

98. Muthusamy, V.; Piva, T.J. The UV response of the skin: A review of the MAPK, NFkB and TNF $\alpha$ signal transduction pathways. Arch. Dermatol. Res. 2010, 302, 5-17. [CrossRef]

99. Schwarz, A.; Ständer, S.; Berneburg, M.; Böhm, M.; Kulms, D.; van Steeg, H.; Grosse-Heitmeyer, K.; Krutmann, J.; Schwarz, T. Interleukin-12 suppresses ultraviolet radiation-induced apoptosis by inducing DNA repair. Nat. Cell Biol. 2002, 4, 26-31. [CrossRef] [PubMed]

100. Kurukulasuriya, L.R.; Stas, S.; Lastra, G.; Manrique, C.; Sowers, J.R. Hypertension in obesity. Med. Clin. N. Am. 2011, 95, 903-917. [CrossRef]

101. Richardson, V.R.; Smith, K.A.; Carter, A.M. Adipose tissue inflammation: Feeding the development of type 2 diabetes mellitus. Immunobiology 2013, 218, 1497-1504. [CrossRef] [PubMed]

102. Albuquerque, K.F.F.S.; Marinovic, M.P.; Morandi, A.C.; Bolin, A.P.; Otton, R. Green tea polyphenol extract in vivo attenuates inflammatory features of neutrophils from obese rats. Eur. J. Nutr. 2016, 55, 1261-1274. [CrossRef] [PubMed]

103. Fenton, J.I.; Nunez, N.P.; Yakar, S.; Perkins, S.N.; Hord, N.G.; Hursting, S.D. Diet-induced adiposity alters the serum profile of inflammation in C57BL/6 N mice as measured by antibody array. Diabetes Obes. Metab. 2009, 11, 343-354. [CrossRef] [PubMed]

104. Chen, S.; Akbar, S.M.F.; Miyake, T.; Abe, M.; Al-Mahtab, M.; Furukawa, S.; Bunzo, M.; Hiasa, Y.; Onji, M. Diminished immune response to vaccinations in obesity: Role of myeloid-derived suppressor and other myeloid cells. Obes. Res. Clin. Pract. 2015, 9, 35-44. [CrossRef] [PubMed]

105. Grant, R.; Youm, Y.H.; Ravussin, A.; Dixit, V.D. Quantification of adipose tissue leukocytosis in obesity. Methods Mol. Biol. 2013, 1040, 195-209.

106. Chatzigeorgiou, A.; Karalis, K.P.; Bornstein, S.R.; Chavakis, T. Lymphocytes in obesityrelated adipose tissue inflammation. Diabetologia 2012, 55, 2583-2592. [CrossRef]

107. Huang, J.; Zhou, Y.; Wan, B.; Wang, Q.; Wan, X. Green tea polyphenols alter lipid metabolism in the livers of broiler chickens through increased phosphorylation of AMP-activated protein kinase. PLoS ONE 2017, 12, e187061. [CrossRef] [PubMed]

108. Rothenberg, D.; Zhou, C.; Zhang, L. A review on the weight-loss effects of oxidized tea polyphenols. Molecules 2018, $23,1176$. [CrossRef]

109. Daniel, G.R.; Schlachter, M.F.; Volker, E.; Weber, P. Effect of EGCG on lipid absorption and plasma lipid levels in rats. J. Nutr. Biochem. 2003, 14, 326-332.

110. Kumazoe, M.; Nakamura, Y.; Yamashita, M.; Suzuki, T.; Takamatsu, K.; Huang, Y.; Bae, J.; Yamashita, S.; Murata, M.; Yamada, S.; et al. Green tea polyphenol epigallocatechin-3-gallate suppresses Toll-like receptor 4 expression via upregulation of E3 ubiquitin-protein ligase RNF. J. Biol. Chem. 2017, 292, 4077-4088. [CrossRef] [PubMed]

111. Yang, C.S.; Chen, G.; Wu, Q. Recent scientific studies of a traditional Chinese medicine, tea, on prevention of chronic diseases. J. Tradit. Complement. Med. 2014, 4, 17-23. [CrossRef] [PubMed]

112. Tang, H.; Hao, S.; Chen, X.; Li, Y.; Yin, Z.; Zou, Y.; Song, X.; Lixia, L.; Ye, G.; Zhao, L.; et al. Epigallocatechin-3-gallate protects immunity and liver drug-metabolism function in mice loaded with restraint stress. Biomed. Pharmacother. 2020, $129,110418$. [CrossRef] [PubMed]

113. Wong, C.P.; Nguyen, L.P.; Noh, S.K.; Bray, T.M.; Bruno, R.S.; Ho, E. Induction of regulatory T cells by green tea polyphenol EGCG. Immunol. Lett. 2011, 139, 7-13. [CrossRef] [PubMed]

114. Kapetanovic, I.M.; Crowell, J.A.; Krishnaraj, R.; Zakharov, A.; Lindeblad, M.; Lyubimov, A. Exposure and toxicity of green tea polyphenols in fasted and non-fasted dogs. Toxicology 2009, 260, 28-36. [CrossRef]

115. Isbrucker, R.A.; Bausch, J.; Edwards, J.A.; Wolz, E. Safety studies on epigallocatechin gallate (EGCG) preparations-Part 1: Genotoxicity. Food Chem. Toxicol. 2006, 44, 626-635. [CrossRef] [PubMed]

116. Reygaert, W.C. Green tea catechins: Their use in treating and preventing infectious diseases. BioMed Res. Int. 2018, $2018,9105261$. [CrossRef]

117. Harikrishnan, R.; Balasundaram, C.; Heo, M.S. Influence of diet enriched with green tea on innate humoral and cellular immune response of kelp grouper Epinephelusbruneus to Vibrio carchariae infection. Fish Shellfish Immun. 2011, 30, 972-979. [CrossRef] [PubMed]

118. Camouse, M.M.; Domingo, D.S.; Swain, F.R.; Conrad, E.P.; Matsui, M.S.; Maes, D.; Declercq, L.; Cooper, K.D.; Stevens, S.R.; Baron, E.D. Topical application of green and white tea extracts provides protection from solar-simulated ultraviolet light in human skin. Exp. Dermatol. 2009, 18, 522-526. [CrossRef]

119. Yang, H.Y.; Yang, S.C.; Chao, J.C.; Chen, J.R. Beneficial effects of catechin-rich green tea and inulin on the body composition of overweight adults. Brit. J. Nutr. 2012, 107, 749-754. [CrossRef] 